\title{
Adsorption of L-amino Acids on Sea Sand
}

\author{
Dimas A. M. Zaia ${ }^{*, a}$, Heberth J. Vieira ${ }^{\#, a}$ and Cássia T. B. V. Zaia \\ ${ }^{a}$ Departamento de Química-CCE and ${ }^{b}$ Departamento de Ciências Fisiológicas-CCB, Universidade Estadual de \\ Londrina, 86051-990 Londrina - PR, Brazil
}

\begin{abstract}
Foi realizado um estudo da adsorção de L-alanina, L-tirosina, L-ácido glutâmico e L-lisina em areia do mar. Somente L-lisina adsorveu na areia do mar, provavelmente devido à sua cadeia lateral que é positivamente carregada. Portanto, estes resultados apontam dúvidas sobre a importância de areia para a pré-concentração de aminoácidos antes condensação de peptídeos na Terra primitiva.

A study of adsorption of L-alanine, L-tyrosine, L-glutamic acid, and L-lysine on sea sand was carried out. Only L-lysine showed adsorption on sea sand, probably due to the presence of the positively charged $\mathrm{R}$ group. Our results raise some doubts as to whether sand was important for the pre-concentration of amino acids prior to peptide condensation on the Pre-Biotic Earth.
\end{abstract}

Keywords: adsorption, sand, amino acids, origin of life

\section{Introduction}

Since 1951, when Bernal ${ }^{1}$ first suggested that mineral clays could have played an important role in the origin of life, because they took part in processes such as selection and concentration of key monomers from dilute solution and their subsequent condensation to biopolymers, much research on this subject has been undertaken.

There are many studies on the adsorption of amino acids $^{2-6}$ as well as other biomolecules, ${ }^{7,8}$ and biopolymers ${ }^{9-13}$ on clays. Clays were used in many experiments because they have a large surface-area-to-volume ratio in comparison with quartz or sand whose surface-area-to-volume ratios are small. However, sand (35-50\%) is more widespread than clays $(25-35 \%) .{ }^{14}$

The present paper describes the utilization of sea sand from Enseada Beach at Guarujá-SP, Brazil, to study the adsorption of the following amino acids: L-alanine, Ltyrosine, L-glutamic acid and L-lysine. Our results raise some doubts about whether sand was important as a concentrator of amino acids.

\section{Material and methods}

Material

Visible spectrophotometry was carried out on a Shimadzu UV-Vis 1203 spectrophotometer. The mineralogical composition of sea sand was determined on a petrographic microscope (KM Plival, Carl Zeiss/Aus Jena Company) and magnifying glass (Carl Zeiss/Aus Jena Company). The sea sand was centrifuged using a Model 243 Microcentrifuge (FANEM Ltda.). All reagents were of analytical grade.

Standard solutions of $20.0 \mathrm{mmol} \mathrm{L}^{-1}$ of the amino acids L-alanine (Nuclear P.A.), L-glutamic acid (Aktron P.A.), Ltyrosine (Merck P.A.) and L-lysine (Merck P.A.) were used in all adsorption experiments. For the dissolution of Ltyrosine and L-glutamic acid it was necessary to add sodium hydroxide.

Sea sand with the following percentage $(\mathrm{m} / \mathrm{m})$ and particle size distribution: $0.02 \%, 0.50-0.42 \mathrm{~mm} ; 15.1 \%$, 0.42-0.149 mm; 0.4\%, 0.15-0.125 mm, and 84.5\%, 0.13$0.074 \mathrm{~mm}$, respectively, was collected from Enseada Beach at Guarujá -SP, Brazil, and was prepared as described by Rohlfing and McAlhaney. ${ }^{15}$

\section{Composition of sea sand}

The mineralogical analysis of sea sand indicates that it is $99 \%$ quartz. Quartz is essentially, pure silica. However,

\footnotetext{
* e-mail: zaiazaia@sercomtel.com.br

\# Present Address: Departamento de Química, Universidade Federal de São Carlos, 13565-905 São Carlos - SP, Brazil
} 
the sea sand is, surely, impure silica. Thus, some (or many) silanol groups would be present and these, even in near neutral $\mathrm{pH}$, present a certain concentration of negative charges $\left(\mathrm{SiO}^{-}\right)$. These will attract the positively charged groups on lysine.

\section{Adsorption of amino acids}

For each amino acid the following procedure was used: $50 \mu \mathrm{L}$ aliquots of $20.0 \mathrm{mmol} \mathrm{L}^{-1}$ of amino acid solutions were added to two different sets of 4 Eppendorff tubes $(1.5 \mathrm{~mL})$. To one set of Eppendorff tubes $100 \mathrm{mg}$ or 200 mg of sea sand was added. To all tubes $450 \mu \mathrm{L}$ of distilled water were added. In some experiments, copper (II) or hydrochloric acid $(\mathrm{HCl})$ or both were added, with the final concentrations $2.0 \mathrm{mmol} \mathrm{L}^{-1}$ and $8.0 \mathrm{mmol} \mathrm{L}^{-1}$, respectively. Experiments with sodium hydroxide $(\mathrm{NaOH})$ or copper (II) plus sodium hydroxide $(\mathrm{NaOH})$ were also carried out. The final concentrations of sodium hydroxide $(\mathrm{NaOH})$ and copper (II) were $8.0 \mathrm{mmol} \mathrm{L}^{-1}$ and $2.0 \mathrm{mmol} \mathrm{L}^{-1}$, respectively. All the Eppendorff tubes were tumbled for $24 \mathrm{~h}$ to permit the adsorption of the amino acids. The tubes with sea sand were spun for 2 min at 2,000 r.p.m. (313 g) and $25 \mu \mathrm{L}$ was removed from each tube.

\section{Determination and recovery of amino acids}

The concentration of all amino acids were carried out using the ninhydrin method as described by Fisher et al. ${ }^{16}$

The recoveries of amino acids from the tubes with sand were calculated using the following equation: Recovery\% $=[$ (concentration of amino acid in the tube with sea sand $) /$ (concentration of amino acid in the tube without sea sand)] $\times 100 \%$.
Comparisons between mean of recoveries (\%) and 100\% were assessed by using Student's t-test at a significance of $\mathrm{p}<0.05$.

\section{Results and Discussion}

Table 1 shows the recoveries of the amino acids Lalanine, L-tyrosine, L-glutamic acid and L-lysine after being tumbled for $24 \mathrm{~h}$ with sea sand in various media. Adsorption on sea sand was not observed for the amino acids L-alanine, L-glutamic acid and L-tyrosine, even when L-alanine and L-glutamic acid were tumbled with copper (II) and hydrochloric acid. Although of L-glutamic acid with copper (II) and hydrochloric acid showed a slight tendency to be adsorbed on sea sand, the recovery was not statistically different from $100 \%$ ( $<<0.05)$. Gupta et al. ${ }^{4}$ showed, using a semi empirical molecular orbital method, that L-alanine bound to copper (II) is adsorbed in the interlamellar space of clays. Rishpon et al. ${ }^{8}$ observed that zinc (II) could increase the adsorption of organic compounds (ATP, ADP) on clays, because of the complex formed between these compounds. Thus, it was expected that the positively charged complex between copper (II) and L-alanine or L-glutamic acid should be adsorbed on negatively charged sea sand. However, the surface-area-to-volume ratio of sand, when compared to clays, is too small and this ratio is probably playing an important role in the adsorption of the amino acids. Among the amino acids used in these experiments, L-lysine showed the most interesting results (Table 1). The adsorption of Llysine on sand (statistically different from 100\%, p<0.05) occurred without addition of copper (II) or acid. The $\mathrm{pH}$ of this sample is 5.3 (Table 1), so the side chain of lysine is positively charged. In this case, probably the positive side chain of L-lysine is playing an important role in the

Table 1. Recoveries of several amino acids after being tumbled for $24 \mathrm{~h}$ with sea sand.

\begin{tabular}{llr}
\hline Amino acid & Conditions & Recovery \\
\hline L-alanine & $100 \mathrm{mg}$ of sea sand/water & $99.0 \pm 1.6\left(3^{\dagger}\right)$ \\
& $200 \mathrm{mg}$ of sea sand/water & $99.7 \pm 2.6\left(4^{\dagger}\right)$ \\
& $200 \mathrm{mg}$ of sea sand/8.0 mmol L-1 of $\mathrm{H}^{+} / 2.0 \mathrm{mmol} \mathrm{L}$ of $\mathrm{Cu}^{2+}$ & $100.4 \pm 2.0\left(3^{\dagger}\right)$ \\
\hline L-tyrosine & $200 \mathrm{mg}$ of sea sand/water & $101.9 \pm 7.4\left(4^{\dagger}\right)$ \\
\hline L-glutamic acid & $100 \mathrm{mg}$ of sea sand/water & $97.7 \pm 4.3\left(2^{\dagger}\right)$ \\
& $200 \mathrm{mg}$ of sea sand/water & $97.6 \pm 5.3\left(4^{\dagger}\right)$ \\
& $200 \mathrm{mg}$ of sea sand/2.0 mmol L-1 of $\mathrm{Cu}^{2+}$ & $97.3 \pm 1.0\left(2^{\dagger}\right)$ \\
& $200 \mathrm{mg}$ of sea sand/8.0 mmol L-1 of $\mathrm{H}^{+}$ & $105.0 \pm 3.5\left(4^{\ddagger}\right)$ \\
& $200 \mathrm{mg}$ of sea sand/8.0 mmol L-1 of $\mathrm{H}^{+} / 2.0 \mathrm{mmol} \mathrm{L}-1 \mathrm{of} \mathrm{Cu}^{2+}$ & $88.1 \pm 5.0\left(5^{\dagger}\right)$ \\
\hline L-lysine & $200 \mathrm{mg}$ of sea sand/8.0 mmol L-1 of $\mathrm{OH}^{-}$ & $102.3 \pm 3.2\left(4^{\ddagger}\right)$ \\
\hline
\end{tabular}

The results are presented as mean \pm standard error of mean. The number of assays is given in parentheses. The pH of the samples after being tumbled for $24 \mathrm{~h}$ were: 5.3 for L-alanine ${ }^{\mathrm{a}}$ and L-lysine ${ }^{\mathrm{a}}, 9.5$ for $\mathrm{L}_{\text {-tyrosine }}{ }^{\mathrm{b}}$ and 7.5 for L-glutamic acid ${ }^{\mathrm{c}}$ without additives. ${ }^{\dagger}$ Number of sets with four samples each set. ${ }^{\sharp}$ One set with four samples. "Statistically different from $100 \%, \mathrm{p}<0.05$. 
adsorption this amino acid on negatively charged sand. Henrichs and Sugai ${ }^{17}$ observed that the adsorption of lysine was greater than the adsorption of glutamic acid, alanine, and leucine in sediments from Resurrection Bay, Alaska. They also suggested that the adsorption of lysine, on the negative surface charge of marine sediments, was due to the positive side chain of lysine.

The results shown in Table 1 raise some questions about the importance of sand as concentration mechanism for amino acids. A study made by Klapper, ${ }^{18}$ about the average occurrence of amino acids in over 200 proteins, showed that the proteins are made up with the following composition: $40.1 \%$ of the amino acids without polar aliphatic R groups; $8.1 \%$ of the amino acids with aromatic R groups; $25.9 \%$ of the amino acids with uncharged polar R groups; $11.7 \%$ of the amino acids with negatively charged $\mathrm{R}$ groups, and $13.8 \%$ of the amino acids with positively charged $\mathrm{R}$ groups. It should be pointed out that the proportion of the amino acids with different side chains in the peptides and proteins is very important for the conformation of those molecules and consequently for the biochemistry of today's organisms. ${ }^{19}$ If $74 \%$ of the proteins amino acids have no charged $\mathrm{R}$ groups and $11.7 \%$ have negatively charged $\mathrm{R}$ groups and sea sand adsorbed only amino acids with positively charged $\mathrm{R}$ groups, how could the adsorption of amino acids on sand be important for the origin of life?

A review paper published by Lahav and Chang ${ }^{5}$ shows the results of adsorption coefficients of several amino acids on apatite, illite and montmorillonite. It was observed that amino acids with charged $\mathrm{R}$ groups are more adsorbed on these clays than amino acids with uncharged $\mathrm{R}$ groups. Bentaleb et $a .^{20}$ studied the adsorption of five different amino acids (alanine, glycine, lysine, threonine, and glutamic acid) on hematite (alpha $\mathrm{Fe}_{2} \mathrm{O}_{3}$ ). They observed that amino acids with a charged side chain (lysine, glutamic acid) adsorb more on hematite than amino acids without a charged side chain (glycine). More recently, other studies of adsorption of amino acids on clays were done involving amino acids with charged $\mathrm{R}$ groups ${ }^{2,3}$ or amino acids plus metals ${ }^{2-4}$ or modified amino acids such as adenylates. ${ }^{6}$ However, they did not made studies comparing adsorption between different amino acids.

\section{Conclusion}

The results of adsorption of amino acids on sea sand show that sand adsorbed the amino acid lysine, which has a positively charged $\mathrm{R}$ group. The amino acids with no charged $\mathrm{R}$ groups (alanine, tyrosine) or a negatively charged $\mathrm{R}$ groups (L-glutamic acid) did not show adsorption on sea sand. It should pointed out that the proteins of today need to have a balance between several proteic amino acids. So, these results raise some doubts as to whether sand was important as a concentrator of amino acids as a step prior to peptide and protein formation.

\section{Acknowledgements}

The authors are much indebted to Dr. Angelo Spoladori from Departamento de GeoCiências-CCE, UEL, for mineralogical analysis of sea sand and stimulating discussions about the composition of sand and clays. This research was supported by grants from CPG/UEL N ${ }^{\circ}$ 374932/98 and CNPq No 470087/01-3.

\section{References}

1. Bernal, J. D.; The Physical Basis of Life, Routledge and Kegan Paul Ltd.: London, 1951.

2. Ding, P. Z.; Kawamura, K.; Ferris, J. P.; Origins Life Evol. Biosphere 1996, 26, 151.

3. Fu, L.; Weckhuysen, B. M.; Verberckmoes, A. A.; Schoonheydt, R. A.; Clays Miner. 1996, 31, 491.

4. Gupta, A.; Loew, G. H.; Lawless, J.; Inorg. Chem. 1983, 22, 111.

5. Lahav, N.; Chang, S.; J. Mol. Evol. 1976, 8, 357.

6. Paecht-Horowitz, M.; Origin Life 1978, 289.

7. Graf, G.; Lagaly, G.; Clays Clay Miner. 1980, 28, 12.

8. Rishpon, J.; O’Hara, P. J.; Lahav, N.; Lawless, J. G.; J. Mol. Evol. 1982, 18, 179.

9. Ertem, G.; Ferris, J. P.; Origins Life Evol. Biosphere 1998, 28, 485.

10. Ferris, J. P.; Ertem, G.; Agarwal, V.; Origins Life Evol. Biosphere 1989, 19, 165.

11. Franchi, M.; Bramanti, E.; Bonzi, L. M.; Orioli, P. L.; Vettori, C.; Gallori E.; Origins Life Evol. Biosphere 1999, 29, 297.

12. Murase, N.; Egami, F.; Origin Life 1978, 391.

13. Orgel, L. E.; Origins Life Evol. Biosphere 1998, 28, 227.

14. Selley, R.C.; An Introduction to Sedimentology, 2nd ed., Academic Press: New York, 1982, p. 77.

15. Rohlfing, D.; McAlhaney, W. W.; BioSystems 1976, 8, 139.

16. Fisher, L. J.; Buting, S. L.; Rosenberg, L. E.; Clin. Chem. 1963, 9, 573.

17. Henrichs, S. M.; Sugai, S. F.; Geochim. Cosmochim. Acta 1993, 57, 823.

18. Klapper, M. H.; Biochem. Biophys. Res. Commun. 1977, 78, 1018.

19. Darnell, J.; Lodish, H.; Baltimore, D.; Molecular Cell Biology, Scientific American Books: New York, 1990, p.48.

20. Bentaleb, V. P.; Delgado, A. V.; Gallardo, V.; Mater. Chem. Phys. 1994, 37, 68. 